TRENDS IN HYDROZOAN BIOLOGY - IV. C.E. MILLS, F. BOERO, A. MIGOTTO and J.M. GILI (eds.)

\title{
Morphology and distribution of a deep-water Narcomedusa (Solmarisidae) from the northeast Pacific*
}

\author{
MARY NEEDLER ARAI ${ }^{1,2}$, MICHAEL J. CAVEY ${ }^{1,3}$ and BEVERLEY A. MOORE ${ }^{1,4}$ \\ ${ }^{1}$ Department of Biological Sciences, University of Calgary, 2500 University Drive N.W., Calgary, Alberta, \\ Canada T2N 1 N4. \\ 2Present address: Pacific Biological Station, Nanaimo, British Columbia, Canada V9R 5K6. E-mail: araim@island.net \\ ${ }^{3}$ Department of Cell Biology and Anatomy, University of Calgary, 3330 Hospital Drive N.W., Calgary, Alberta, \\ Canada T2N 4N1. E-mail: mcavey@ucalgary.ca \\ ${ }^{4}$ Present address: Division of Gastroenterology/Hepatology, Department of Medicine, University of Pittsburgh, PA 15261, \\ USA. E-mail: beverly-moore@hotmail.com
}

\begin{abstract}
SUMMARY: Specimens of Solmaris sp. (Solmarisidae, Narcomedusae) with only four tentacles were collected in the northeast Pacific. The majority were collected in Canadian Pacific waters by Tucker trawl from stations outside the 500-m contour off the west coast of Vancouver Island, British Columbia, at depths of 300-700 m. Six were collected in vertical hauls at Station $P\left(50^{\circ} \mathrm{N}, 145^{\circ} \mathrm{W}\right)$. The oral stomach wall contains three prominent rings of tissue. There is a peripheral ring of aggregates of gonadal tissue. Nematogenic areas with three types of nematocysts form an intermediate ring closer to the mouth than the gonads, and they also overlie the gonadal position where nematogenic tissue extends out to the base of each tentacle. Immediately surrounding the mouth, the epithelium of the oral stomach wall is greatly thickened, and this central ring contains large numbers of secretory cells.
\end{abstract}

Key words: nematocysts, Solmaris, Hydrozoa, distribution, anatomy.

\section{INTRODUCTION}

The inshore fauna of the Hydrozoa (medusa stage) from Puget Sound and off British Columbia is fairly well known (summarized in Arai and Brinckmann-Voss [1980] and Mills [1987]). However, there are few published data on the deep-water fauna from Canadian and adjacent waters of the northeast Pacific Ocean. A recent book by Wrobel and Mills (1998) has included some data on deep-water forms of the region in a guide to the west coast of North America from Baja California to Alaska. Since

\footnotetext{
*Received March 1, 1999. Accepted January 25, 2000.
}

1980, collections in Canadian Pacific waters (within the 200-mile limit) have provided specimens of a number of deep-water species of coelenterates (Fulton et al., 1982; Arai et al., 1993), and a series of papers on this fauna has been started. A paper on the Anthoathecatae and Tiarannidae was recently published (Brinckmann-Voss and Arai, 1998). The present paper describes a previously-undescribed narcomedusa, and it is expected that other papers will follow.

In spring, the most abundant narcomedusa from outer Canadian Pacific waters is a small Solmaris with only four tentacles. In recent years, approximately 900 specimens have been collected. The 
species is similar to Solmaris quadrata Bouillon, Boero and Seghers, 1991, described from seven specimens collected off Papua New Guinea. The present paper describes the known distribution, anatomy, and histology of the Canadian form.

\section{MATERIAL AND METHODS}

\section{Collection of specimens}

Most specimens were collected off the west coast of Vancouver Island, British Columbia, Canada. Of these, the majority were collected off the southwest coast in January to May of 1987 and February to March of 1988 (Arai et al., 1993). The study area included the La Perouse Bank area and associated slope waters. Twenty stations were sampled along two transect lines, approximately $36 \mathrm{~km}$ apart, laid out approximately perpendicular to the bottom contours from off Barkley Sound and Pachena Point. Each line extended from 8 to $200 \mathrm{~km}$ from shore, with sampling stations $10-20 \mathrm{~km}$ apart (see maps and individual station locations in McFarlane and Beamish [1992] and Arai et al. [1993]).

Discrete samples were taken at 300,500, and 700 $\mathrm{m}$ at each station using a $1-\mathrm{m}^{2}$ Tucker trawl that opened and closed at depth. Each trawl unit consisted of three nets. When deploying this gear, the bottom net was open with the middle and top nets closed. After reaching the desired discrete depth, the middle net was opened and the top and bottom nets were closed for a tow duration of approximately 15 min at that depth. During retrieval the top net was open. The three depths were chosen for sampling (together with surface neuston tows) in order to give maximum information about sablefish larvae and associated fauna during their ontogenetic migration to the surface from a depth of approximately 1,000 m (McFarlane and Beamish, 1992). Each net of 335$\mu \mathrm{m}$ black nitex mesh was equipped with a rigid cod end with a $335-\mu \mathrm{m}$ screen and a flowmeter. Samples were preserved in 4 or $5 \%$ buffered sea waterformaldehyde.

Earlier, in 1980 and 1986, samples off the Canadian west coast were obtained by oblique bongo tows which did not yield discrete depth data (see maps and station locations in Fulton et al. [1982] and Arai et al. [1993]).

Canadian weatherships at Ocean Station $P$ ("Papa"; $50^{\circ} \mathrm{N}, 145^{\circ} \mathrm{W}$, outside Canadian waters in the northeast Pacific) were used as oceanographic sampling stations from 1956 to 1980 (Waddell and McKinnell, 1995). In addition to daily vertical hauls to $150 \mathrm{~m}$, occasional vertical hauls were made to 1,200 m using SCOR, Miller, or NORPAC nets.

\section{Histology and morphometry}

Several specimens were prepared for lightmicroscopic examination in glycol-methacrylate sections. For photography, two specimens (4.8 and $5.0 \mathrm{~mm}$ diameter) were soaked in $0.1 \mathrm{M}$ phosphate buffer ( $\mathrm{pH} \mathrm{8)}$ to remove excess fixative, and infiltrated and embedded in glycol methacrylate, using a Historesin kit (LKB, Heidelberg, Germany). Sections (3-5 $\mu \mathrm{m}$ in thickness) were cut with glass (Ralph) knives on a rotary microtome. Sections were transferred to puddles of demineralized water on microscope slides, and they were then stretched and affixed by heating. To augment staining, sections were treated with $1 \%$ periodic acid for 10-15 min. An alcoholic solution of methylene blue and basic fuchsin was applied to the sections at room temperature (Bennett et al., 1976). Background staining was eliminated by dipping sections in $95 \%$ ethanol, and the sections were then allowed to airdry thoroughly. Cover glasses were mounted with Fisher Permount.

The semithin histological sections were viewed and photographed with a Nikon Optiphot compound microscope equipped with planachromatic objective lenses and an AFX-II photomicrographic attachment. The microscope was calibrated with a stage micrometer (100 lines $/ \mathrm{mm}$ ).

Three whole specimens (4.0-4.5 $\mathrm{mm}$ diameter) were squashed in distilled water. Nematocyst masses were transferred to microscope slides, and supported cover glasses were added. Nematocysts were viewed and photographed with Nomarski differential interference-contrast optics.

Three types of nematocysts, initially recognized morphologically in the glycol-methacrylate sections, were also evident in the squashes. Photomicrographs of the nematocysts were digitized, and for each type, the circumferences of 25 specimens were measured, using "Sigma Scan" 3.02 software (Jandel Scientific, San Rafael, California, U.S.A.). Since all three types of nematocyst are essentially spherical in shape, each circumference (c) was treated as the perimeter of a circle. By calculating the radius (r) of a circle $(r=c / 2 \pi)$, it was then possible to insert the radius into the formula for the volume (v) of a sphere $\left(v=4 \pi r^{3} / 3\right)$. Calculations were made in 
"Quatro Pro" 6.0 software (Corel Corporation, Ottawa, Ontario, Canada), and the volumetric data were plotted with "Sigma Plot for Windows" 4.0 software (SPSS, Chicago, Illinois, U.S.A.).

\section{RESULTS}

\section{Distribution of medusae}

Off the west coast of Vancouver Island, specimens of Solmaris sp. have so far been collected only from stations outside the 500-m contour at latitudes between $47^{\circ} 57^{\prime} \mathrm{N}$ and $50^{\circ} 30^{\prime} \mathrm{N}$. In 1987 and 1988 , Tucker samples were collected along two lines of stations southwest of Vancouver Island as detailed in the above. Although collections off Pachena Point and Barkley Sound were made at inshore stations and across the La Perouse Bank (as well as beyond to the $1,200-\mathrm{m}$ contour line), no specimens were obtained from inshore or bank stations.

Weather permitting, samples were collected at each station at the three discretely-sampled depths $(300,500$, and $700 \mathrm{~m})$. Table 1 presents the data from the six stations outside the 500-m contour for which 1987 data are most complete. This year is presented because, in 1988, no sample exceeded 3.1 individuals per $1,000 \mathrm{~m}^{3}$, whereas in 1987 , populations of up to 20 medusae per $1,000 \mathrm{~m}^{3}$ were recorded (Table 1). Of the three depths, the medusae were usually most abundant at $500 \mathrm{~m}$ during daylight (Table 1), whereas at night, they may be more abundant at $300 \mathrm{~m}$. In 1987 Solmaris sp. constituted about $40 \%$ of the narcomedusae collected at these stations.

In addition to the specimens from Canadian Pacific waters, six specimens were obtained from Station $P\left(50^{\circ} \mathrm{N}, 145^{\circ} \mathrm{W}\right)$. These medusae were collected in vertical hauls to $1,200 \mathrm{~m}$ with a SCOR net, so no depth data are available for this location.

\section{Anatomy}

Like all narcomedusae, the medusae lack radial canals. The umbrella is a somewhat-flattened, slightly-quadratic dome with a diameter in the present collections from 4 to $11 \mathrm{~mm}$. Four tentacles leave the umbrella at the level of the stomach (Fig. $1 \mathrm{~A})$, each above a peronium so that the margin is divided into four lobes (Fig. 1A). The tentacles are solid, each with a root curving upward into the mesoglea above the stomach (Figs. 1A, 1D) and
TABLE 1. - Abundance of Solmaris sp. at six stations off southwest Vancouver Island in 1987. For each set of tows, abundance was assessed at two or three depths.

\begin{tabular}{lll}
\hline $\begin{array}{l}\text { Depth } \\
(\mathrm{m})\end{array}$ & $\begin{array}{l}\text { Specimens } \\
\text { per } 1,000 \mathrm{~m}^{3}\end{array}$ & Date \\
\hline $47^{\circ} 57^{\prime} \mathrm{N} 126^{\circ} 26^{\prime} \mathrm{W}$ & & \\
300 & 1.1 & 26 January (night) \\
500 & 0.0 & 26 January (day) \\
300 & 0.0 & 21 February (night) \\
500 & 9.8 & 21 February (night) \\
700 & 0.3 & 21 February (night) \\
300 & 17.8 & 21 March (night) \\
500 & 2.9 & 21 March (night) \\
700 & 0.8 & 21 March (night)
\end{tabular}

$48^{\circ} 09^{\prime} \mathrm{N} 126^{\circ} 00^{\prime} \mathrm{W}$

$\begin{array}{lll}300 & 0.7 & 27 \text { January (day) } \\ 500 & 6.6 & 27 \text { January (day) } \\ 300 & 0.0 & 21 \text { February (day) } \\ 500 & 8.9 & 21 \text { February (day) } \\ 700 & 0.3 & 21 \text { February (day) } \\ 300 & 2.5 & 16 \text { March (night) } \\ 500 & 1.4 & 16 \text { March (day) } \\ 700 & 0.0 & 16 \text { March (day) }\end{array}$

$48^{\circ} 11^{\prime} \mathrm{N} 125^{\circ} 56^{\prime} \mathrm{W}$

$\begin{array}{lll}300 & 2.1 & 03 \text { February (day) } \\ 500 & 1.0 & \text { 03 February (night) } \\ 300 & 0.0 & 18 \text { February (day) } \\ 500 & 5.6 & 18 \text { February (day) } \\ 700 & 1.9 & 18 \text { February (night) } \\ 300 & 0.0 & 20 \text { March (night) } \\ 500 & 5.9 & 20 \text { March (day) } \\ 700 & 2.8 & 20 \text { March (day) }\end{array}$

$48^{\circ} 15^{\prime} \mathrm{N} 126^{\circ} 40^{\prime} \mathrm{W}$

$\begin{array}{lll}300 & 0.0 & 25 \text { January (day) } \\ 500 & 0.8 & 25 \text { January (day) } \\ 300 & 1.8 & 17 \text { February (night) } \\ 500 & 0.6 & 17 \text { February (night) } \\ 700 & 2.1 & 17 \text { February (day) } \\ 300 & 4.1 & 16 \text { March (night) } \\ 500 & 1.9 & 16 \text { March (night) } \\ 700 & 1.0 & 15 \text { March (night) }\end{array}$

$48^{\circ} 22^{\prime} \mathrm{N} 126^{\circ} 20^{\prime} \mathrm{W}$

$\begin{array}{lll}300 & 0.0 & \text { 24 January (day) } \\ 500 & 21.8 & \text { 24 January (day) } \\ 300 & 0.0 & \text { 16 February (day) } \\ 500 & 14.1 & \text { 16 February (day) } \\ 700 & 0.0 & \text { 16 February (day) } \\ 300 & 1.0 & 15 \text { March (night) } \\ 500 & 2.3 & 15 \text { March (day) } \\ 700 & 0.5 & 15 \text { March (day) }\end{array}$

$48^{\circ} 26^{\prime} \mathrm{N} 126^{\circ} 14^{\prime} \mathrm{W}$

$\begin{array}{lll}300 & 0.0 & 23 \text { January (day) } \\ 500 & 7.5 & \text { 24 January (day) } \\ 300 & 1.5 & \text { 16 February (night) } \\ 500 & 6.9 & \text { 16 February (day) } \\ 300 & 7.8 & \text { 22 March (night) } \\ 500 & 2.8 & \text { 22 March (night) }\end{array}$

with an external length of at least 2.5 times the diameter of the bell.

The stomach is broad and circular, without pouches. The oral stomach wall of mature specimens contains a peripheral ring of aggregates of gonadal tissue 

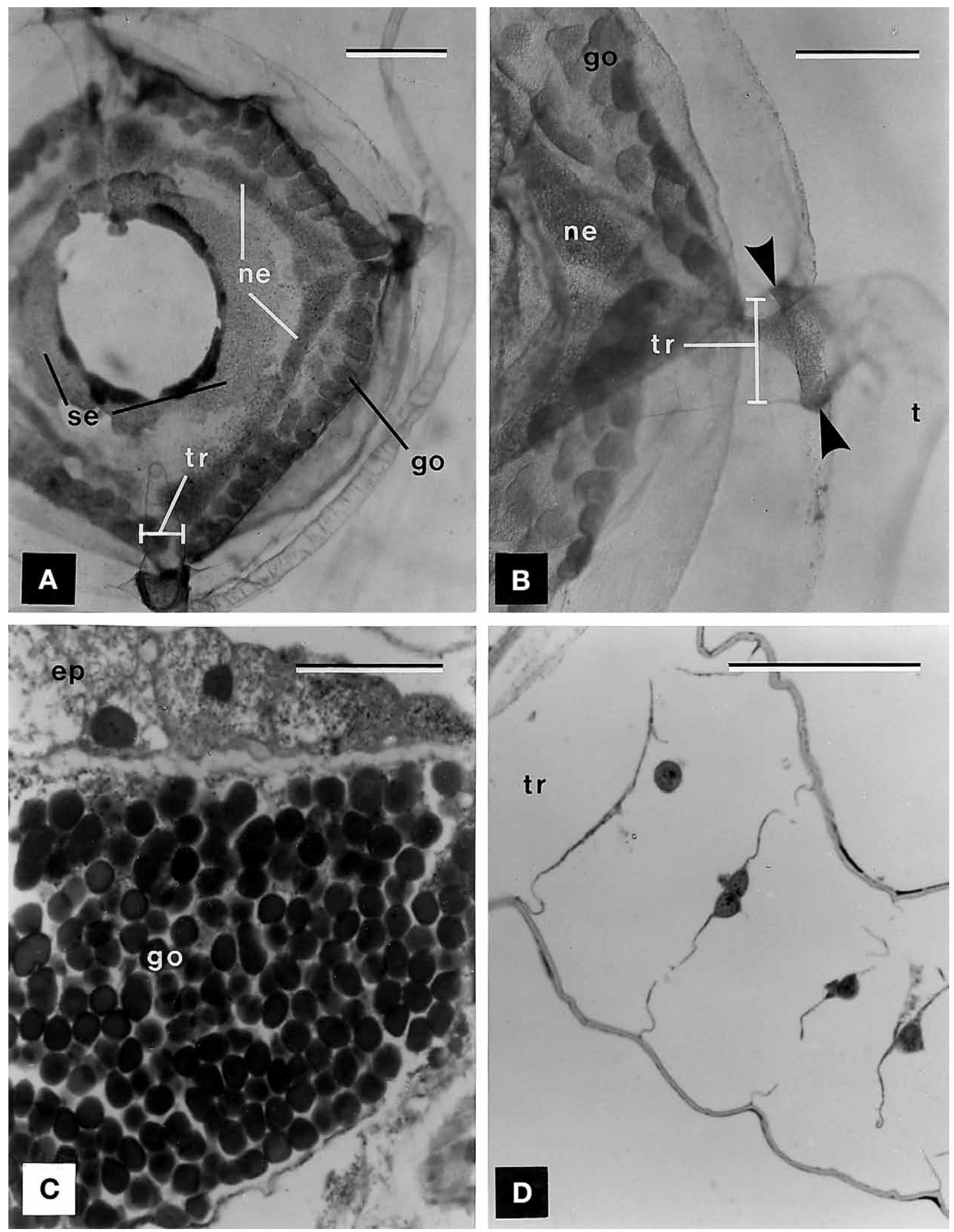

FIG. 1. - A. Aboral view of a 6.5-mm medusa revealing the three tissues (go, gonadal tissue; ne, nematogenic tissue; se, secretory tissue) in the oral wall of the stomach observed though the transparent umbrella. Note the ring of discrete aggregations of gonadal tissue. tr, root of a tentacle. Scale bar $=1 \mathrm{~mm}$. B. Aboral view of a medusa illustrating the connection of nematogenic tissue (ne) of the oral stomach wall to a semicircular band (between arrowheads) at the base of a tentacle. go, gonad; t, tentacle; tr, root of a tentacle. Scale bar $=0.5 \mathrm{~mm}$. C. Photomicrograph of a glycol-methacrylate section through the oral wall of the stomach, illustrating the structure of a single aggregate of gonadal tissue and the overlying epithelium (ep). go, gonad. Scale bar $=100 \mu \mathrm{m}$. D. Photomicrograph of a glycol-methacrylate section through the endodermal root of a tentacle (tr). Scale bar $=100 \mu \mathrm{m}$. 

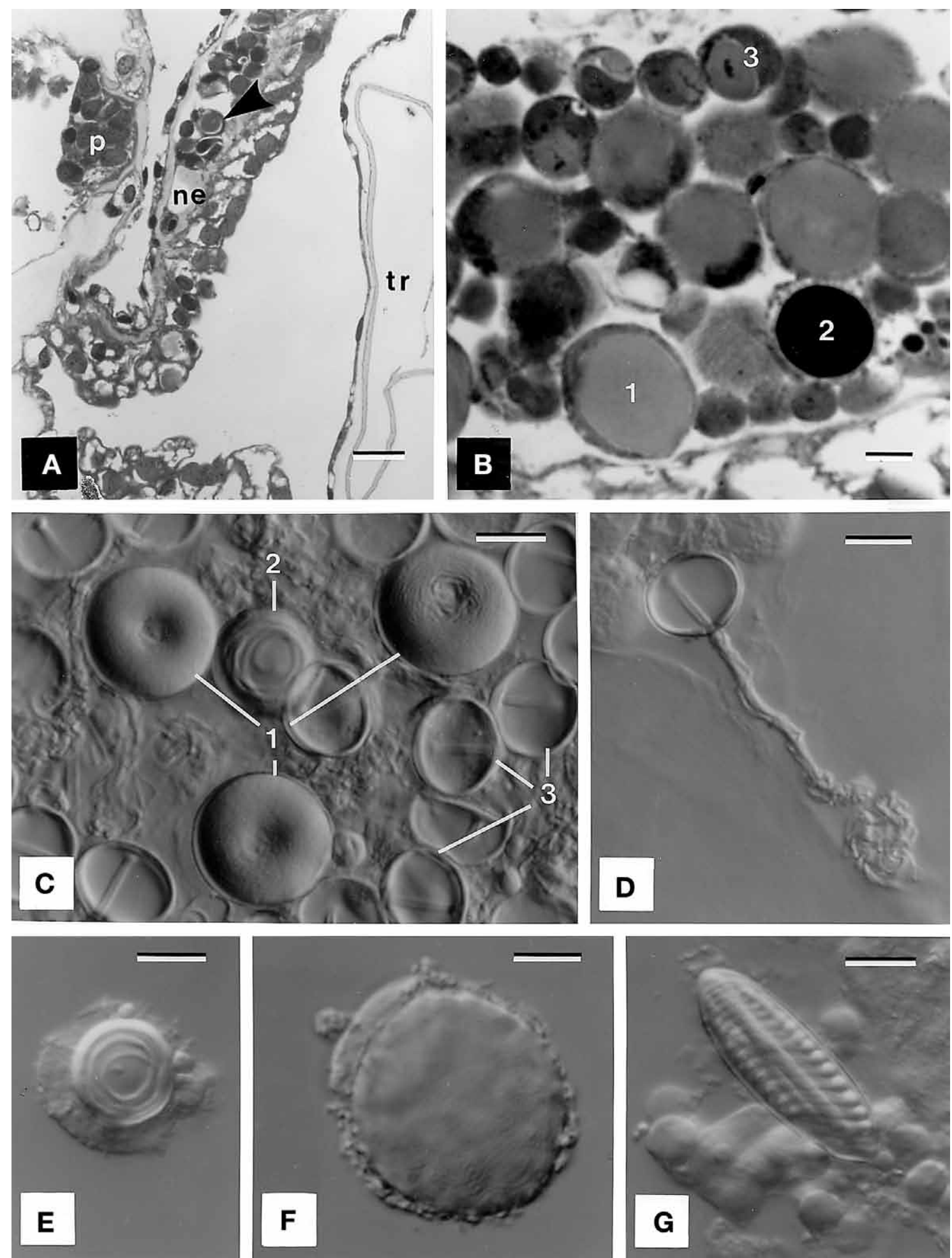

FIG. 2. - A. Photomicrograph of a glycol-methacrylate section of the margin of the umbrella, where nematogenic tissue (ne) of the oral stomach wall approaches the margin. Nematocysts (arrowhead) are apparent. p, peronium without canal; tr, root of a tentacle. Scale bar $=10 \mu \mathrm{m}$. B. Photomicrograph of a glycol-methacrylate section of the nematogenic tissue in the oral stomach wall. Three types of nematocysts can be identified on the basis of morphology and size (see text): Type-1 nematocysts (1) are large and without stained internal structure, Type-2 nematocysts (2) are intermediate in size and intensely stained, and Type-3 nematocysts (3) are small with a stained irregular bar. Scale bar = $10 \mu \mathrm{m}$. C. Squash of a whole medusa viewed with Nomarski optics. The three types of spherical nematocysts (1, Type-1 nematocyst; 2 , Type2 nematocyst; 3 , Type-3 nematocyst) are easily identified. The Type-3 nematocysts are invariably everted in squashes. Scale bar $=10 \mu \mathrm{m}$. D. Everted Type-3 nematocyst. Squash viewed with Nomarski optics. Scale bar $=10 \mu \mathrm{m}$. E. Type-2 nematocyst in its nematocyte. Squash viewed with Nomarski optics. Scale bar $=10 \mu \mathrm{m}$. F. Type-1 nematocyst in its nematocyte. Squash viewed with Nomarski optics. Scale bar $=10 \mu \mathrm{m}$. G. Rare Type-4 ovoid nematocyst which has not been observed in sections of whole animals and which may belong to prey. Squash viewed with Nomarski optics. Scale bar $=10 \mu \mathrm{m}$ 
(Figs. 1A and 1C). Nematogenic areas form an intermediate ring closer to the mouth than the gonads and also overlie the gonadal position where nematogenic tissue extends out to a semicircular band at the base of each tentacle (Figs. 1A and 1B). Immediately surrounding the simple mouth, the epithelium of the oral stomach wall is thickened with large numbers of secretory cells (Fig. 1A).

The margins of the medusae are very fragile. The umbrella with attached tentacles is easily distinguished from any other species in the tows. However, in spite of examination of almost 900 specimens, none have been found with exumbrellar lobes undamaged from the collecting stress, so the sense organs and any associated otoporpae have not been observed. The tissue in the peronia below the tentacle bases lacks canals (Fig. 2A), so a peripheral canal system is probably not present on the exumbrellar lobes.

\section{Histology}

The glycol-methacrylate sections were used to identify the gonodal tissue, nematogenic tissue, and secretory tissue of the oral stomach wall. Both sections and squashes of whole animals were used to examine the nematocysts present in the medusa within the limitations of bright-field and Nomarski differential interference-contrast microscopy.

In stained sections, three types of spherical nematocysts within nematocytes were identified by their morphology (Fig. 2B of nematogenic tissue). The largest nematocyst (Type 1) shows no stained internal structure when sectioned (Fig. 2B). The next- smaller size (Type 2) is often intensely stained in sections (Fig. 2B). The smallest spherical nematocyst (Type 3) has a stained irregular bar in sections (Fig. 2B).

The above three types of nematocysts and a rare fourth ovoid type were also present in squashes of whole medusae (Figs. 2C-2G). Types 1 and 2 did not evert, presumably due to prior fixation. Examined with Nomarski optics Type 2 is clearly seen to contain loosely-coiled structures, presumably tubules which are isodiametric or of evenly-reduced diameter (Figs. 2C and 2E). Some indication of finelycoiled structures may be present in Type 1 using Nomarski optics but details could not be observed (Figs. 2C and 2F). In squashes, Type 3 is everted with a tubule that is apotrichous (with spines on the distal portion of the tubule) at the level of light microscopy and with a remaining bar within the capsule (Figs. 2C and 2D). The ovoid nematocyst (Type

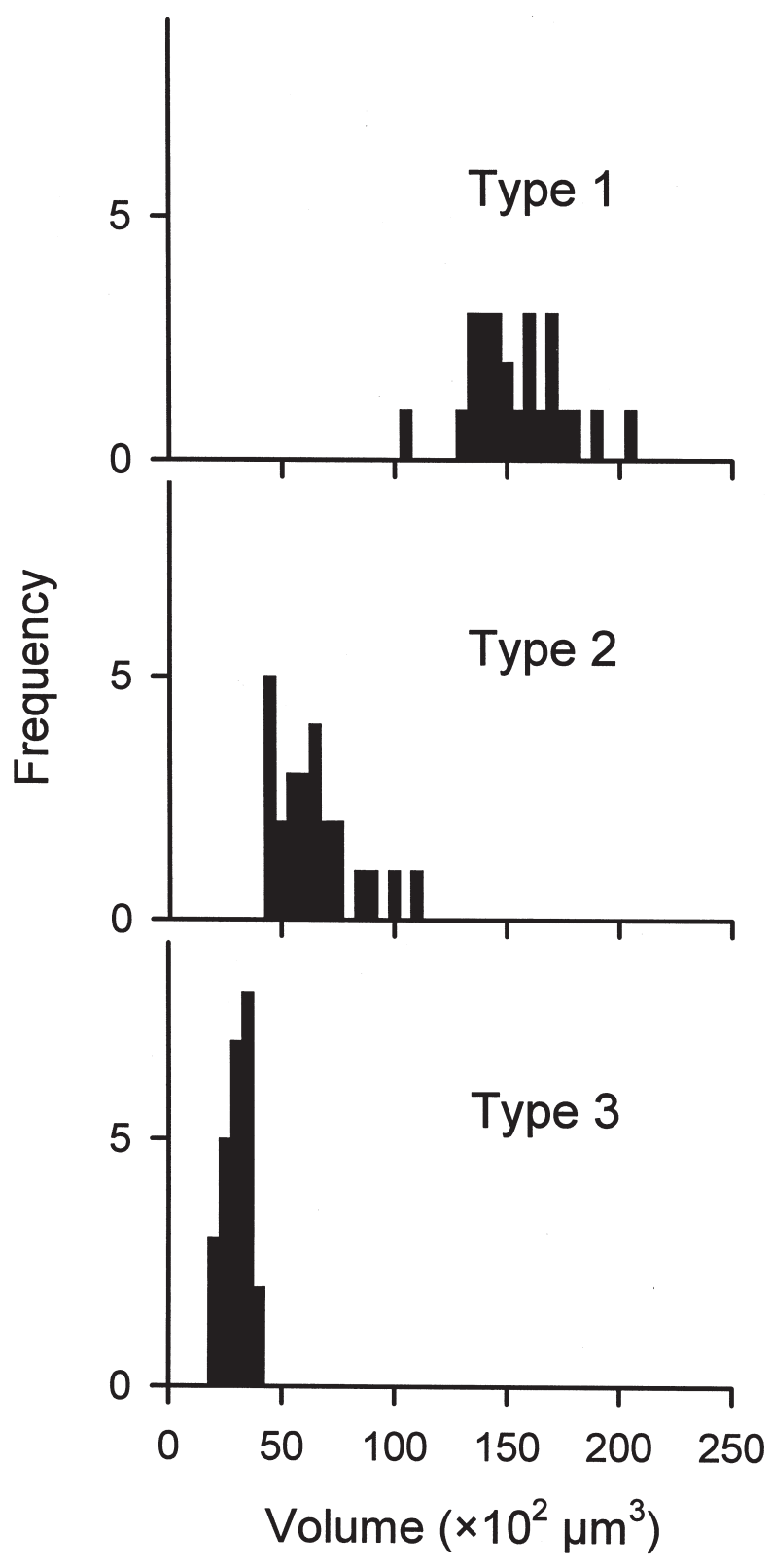

FIG. 3. - Volumetric comparison of the spherical (Type-1, Type-2, and Type-3) nematocysts. Volumes were calculated for 25 nematocysts of each type and plotted at increments of $500 \mu \mathrm{m}^{3}$. There is little overlap between the three types.

4) has a longitudinal shaft surrounded by a coiled tubule. It is extremely rare, observed only twice in squashes.

In squashes the diameters of 25 Type- 1 nematocysts ranged from 27.0 to $33.8 \mu \mathrm{m}$ (mean $30.7 \pm 1.4$ $\mu \mathrm{m}$ ), of 25 Type- 2 nematocysts ranged from 19.8 to $27.4 \mu \mathrm{m}$ (mean $22.6 \pm 2.0 \mu \mathrm{m}$ ), and of Type-3 nematocysts ranged from 15.4 to $19.8 \mu \mathrm{m}$ (mean $17.5 \pm 1.2$ $\mu \mathrm{m})$. The volumes of the three types of spherical nematocysts were calculated, and the frequencies were plotted at increments of $500 \mu \mathrm{m}^{3}$ (Fig. 3). Due 
to eversion of the Type 3 and fixation of all three types of nematocysts, caution must be used in comparing these measurements of diameters with absolute values from fresh squashes of other narcomedusae. The measurements do, however, clearly demonstrate that the three morphological types present in whole animals fall into three distinct size classes as shown in Figure 3. Similar size classes are found in other narcomedusae.

\section{DISCUSSION}

\section{Taxonomy}

The medusae are clearly narcomedusae of the family Solmarisidae, because they lack stomach pouches. Since there is a simple ring of gonadal tissue without diverticula and since no canals have been seen in the peronial tissue near the bases of the tentacles (Fig. 2A), the medusae are referred to the genus Solmaris rather than Pegantha (Kramp, 1961; Bouillon, 1985). In the northeast Pacific, species of Solmaris with more than four tentacles (including $S$. coronata and S. rhodoloma) have been reported off central and southern California and Mexico (Alvarino, 1980, 1985; Segura-Puertas, 1984; Wrobel and Mills, 1998). The present specimens, however, most resemble $S$. quadrata Bouillon, Boero and Seghers, 1991, the only species previously described with only four tentacles.

Based on seven specimens from Papua New Guinea, Bouillon et al. (1991) diagnosed S. quadrata as: Solmaridae of quadratic form, flattened, of small size, up to $1.2 \mathrm{~mm}$ diameter; exumbrellar lobes little developed, slightly convex; four tentacles; two statocysts per exumbrellar lobe, gonads differentiated on almost the whole subumbrellar wall of the stomach. They also noted relatively-short tentacles. In contrast to the diagnosis, the drawing shows a specimen of over $2 \mathrm{~mm}$ diameter with tentacles each approximately $1 \mathrm{~mm}$ in length. The authors state that the types are deposited in the Institut Royal des Sciences Naturelles de Belgique, however such specimens are not listed in the 1995 collection list of that institute (Bouillon et al., 1995) so their location is unknown.

Until specimens of the Canadian Pacific form are collected with intact lobes and sense organs, it is not possible to clearly identify the form as, or distinguish it from, Solmaris quadrata. It differs from the previous description of $S$. quadrata in larger maxi- mum size to $11 \mathrm{~mm}$ diameter, longer tentacles to at least 2.5 times the diameter of the umbrella, and less extensive disposition of the gonads on the subumbrellar wall. These latter characters may not prove to be of specific value when specimens of the Canadian form of less than $4 \mathrm{~mm}$ diameter are available for examination.

Although the present data show that this species is abundant offshore, at least in spring, it has not been recorded previously from Canadian or other North Pacific waters. The small and delicate specimens are usually damaged in nets. Offshore collections from submarines have not been made in this area, and individuals are in any case smaller than is normally visible to observers in manned submarines (C.E. Mills, pers. comm.). These factors will make it difficult to collect the even smaller juvenile specimens necessary to resolve the taxonomic questions. Until those questions are resolved, it is premature to speculate on the range of the species beyond the northeast Pacific.

\section{Nematocysts}

This is the first paper to examine the nematocysts of a solmarisid narcomedusa. In other species of narcomedusae, spherical nematocysts of two sizes have been observed on the tentacles (Bouillon et al., 1988; Purcell and Mills, 1988; Carré et al., 1989). The tubule is of the same diameter throughout (isorhiza), or tapers very gradually, so that it is evenly coiled in the undischarged capsule. Depending partly on the degree of magnification used in the observation, these nematocysts have been described as atrichous (without spines) or apotrichous (with spines on the distal portion of the tubule) when examined by light microscopy. However Carré et al. (1989) showed that small spines may be present throughout the length of the tubule which are visible only with the transmission electron microscope. These nematocysts correspond to the Type- 1 and Type-3 nematocysts of the present Solmaris sp. The appearance of the unexploded Type- 1 nematocysts is similar to that of the larger nematocysts of Aegina citrea tentacles (see Fig. 2 in Mills and Miller [1984]).

A third type of spherical nematocyst has been observed in the subumbrella and exumbrella of Aegina citrea and Solmissus spp. (Mackie and Mackie, 1963; Mills and Goy, 1988). Three types are also present in the aberrant hydrozoan Polypodium hydriforme which has been placed in the nar- 
comedusae by some authors (Raikova, 1990). This third type corresponds to the Type-2 nematocyst of the present Solmaris sp. Figure 2E of the present paper may be compared with Figure $4 \mathrm{~b}$ of Mills and Goy (1988).

In addition, a fourth type of nematocyst was rarely present in squashes of whole animals of Solmaris sp. This nematocyst (Type 4) is ovoid with a tubule possessing a well-developed shaft (i.e. it is a heteroneme) (Fig. 2G). This would be very unusual for the narcomedusae. It was not found in the histological sections, so it is not documented as belonging to the tissue of Solmaris. Narcomedusae usually have a diet of other gelatinous animals, including other hydromedusae (Mills and Goy, 1988; Purcell and Mills, 1988; Larson et al., 1989). It is probable that this nematocyst belongs to the remnants of a prey species in the stomach.

\section{ACKNOWLEDGEMENTS}

Most samples from Canadian waters were collected by the Groundfish Section of the Pacific Biological Station (P.B.S.), Nanaimo, British Columbia, Canada. Samples from Station $P$ were made available by J. Fulton, also of the Pacific Biological Station. Sorting of coelenterates at that laboratory from these field samples was carried out by K. Thompson, I.M. Chan, T.E. Appleton, J.E. Strong, and M.D. Binstead. We are grateful to R.J. Beamish and D. Noakes for provision of the space and facilities at P.B.S. Sorting was supported by DFO/NSERC Subventions (grants) awarded to M.N. Arai (G.A. McFarlane, Fisheries and Oceans liaison officer) or by NSERC Grant A2007. Anatomical and histological work at the University of Calgary was supported by NSERC Grants A2007 to M.N. Arai and A0484 to M.J. Cavey.

\section{REFERENCES}

Alvarino, A. - 1980. The relation between the distribution of zooplankton predators and anchovy larvae. CalCOFI Rep., 21: $150-160$.

Alvarino, A. - 1985. Las surgencias en la region de California-Baja California: Relaciones con el zooplancton y poblaciones de Engraulis mordax (Pisces). Inv. Mar. CICIMAR, 2: 81-102.

Arai, M.N. and A. Brinckmann-Voss. - 1980. Hydromedusae of
British Columbia and Puget Sound. Can. Bull. Fish. Aquat. Sci., 204: 1-192.

Arai, M.N., G.A. McFarlane, M.W. Saunders and G.M. Mapstone. - 1993. Spring abundance of medusae, ctenophores, and siphonophores off southwest Vancouver Island: Possible competition or predation on sablefish larvae. Can. Tech. Rep. Fish. Aquat. Sci., 1939: 1-37.

Bennett, H.S., A.D. Wyrick, S.W. Lee and J.H. McNeil, Jr. - 1976. Science and art in preparing tissues embedded in plastic for light microscopy, with special reference to glycol methacrylate, glass knives and simple stains. Stain Technol., 51: 71-97.

Bouillon, J. - 1985. Essai de classification des HydropolypesHydromedusés (Hydrozoa-Cnidaria). Indo-Malay. Zool., 1: 29243.

Bouillon, J., G. Seghers and F. Boero. - 1988. Note sur les cnidocystes des hydroméduses de la mer de Bismarck (Papouasie Nouvelle Guineé). Indo-Malay. Zool., 5: 203-224.

Bouillon, J., F. Boero and G. Seghers. - 1991. Notes additionelles sur les méduses de Papouasie Nouvelle-Guinée (Hydrozoa, Cnidaria) IV. Cah. Mar. Biol., 32: 387-411.

Bouillon, J., C. Massin and R. Kresevic. - 1995. Hydroidomedusae de l'Institut royal des Sciences naturelles de Belgique. Doc. Trav. Inst. R. Sci. Nat. Belg., 78: 1-106.

Brinckmann-Voss, A. and M.N. Arai. - 1998. Further notes on Leptolida (Hydrozoa: Cnidaria) from Canadian Pacific waters. Zool. Verh. Leiden, 323: 37-68.

Carré, D., C. Carré and C.E. Mills. - 1989. Novel cnidocysts of narcomedusae and a medusivorous ctenophore, and confirmation of kleptocnidism. Tissue Cell, 21: 723-734.

Fulton, J., M.N. Arai and J.C. Mason. - 1982. Euphausiids, Coelenterates, Ctenophores, and Other Zooplankton from the Canadian Pacific Coast Ichthyoplankton Survey, 1980. Can. Tech. Rep. Fish. Aquat. Sci., 1125: 1-75.

Kramp, P.L. - 1961. Synopsis of the Medusae of the World. J. Mar. Biol. Ass. U.K., 40: 7-469.

Larson, R.J., C.E. Mills and G.R. Harbison. - 1989. In situ foraging and feeding behaviour of narcomedusae (Cnidaria, Hydrozoa). J. Mar. Biol. Ass. U.K., 69: 785-794.

Mackie, G.O. and G.V. Mackie. - 1963. Systematic and biological notes on living hydromedusae from Puget Sound. Nat. Mus. Can. (Contrib. Zool.) Bull., 199: 63-84.

McFarlane, G.A. and R.J. Beamish. - 1992. Climatic influence linking copepod production with strong year-classes in sablefish, Anoploma fimbria. Can. J. Fish. Aquat. Sci., 49: 743-753.

Mills, C.E. - 1987. Hydromedusae. In: E. Kozloff: Marine Invertebrates of the Pacific Northwest, pp. 32-44. University of Washington Press, Seattle.

Mills, C.E. and J. Goy. - 1988. In situ observations of the behavior of mesopelagic Solmissus narcomedusae (Cnidaria, Hydrozoa). Bull. Mar. Sci., 43: 739-751.

Mills, C.E. and R.L. Miller. - 1984. Ingestion of a medusa (Aegina citrea) by the nematocyst-containing ctenophore Haeckelia rubra (formerly Euchlora rubra): phylogenetic implications. Mar. Biol., 78: 215-221.

Purcell, J.E. and C.E. Mills. - 1988. The correlation between nematocyst types and diets in pelagic Hydrozoa. In: D.A. Hessinger and H.M. Lenhoff (eds.): The Biology of Nematocysts, pp. 463485. Academic Press, San Diego.

Raikova, E.V. - 1990. Fine structure of the nematocytes of Polypodium hydriforme Ussov (Cnidaria). Zool. Scr., 19: 1-11.

Segura-Puertas, L. - 1984. Morphology, systematics and zoogeography of medusae (Cnidaria: Hydrozoa and Scyphozoa) from the Eastern Tropical Pacific. Inst. Cienc. del Mar y Limnol. Univ. Nat. Auton. Mexico Publ. Esp., 8: 1-320.

Waddell, B.J. and S. McKinnell. - 1995. Ocean Station "Papa" detailed zooplankton data: 1956-1980. Can. Tech. Rep. Fish. Aquat. Sci., 2056: 1-21.

Wrobel, D. and C.E. Mills. - 1998. Pacific Coast Pelagic Invertebrates: A Guide to the Common Gelatinous Animals. Sea Challengers and Monterey Bay Aquarium, Monterey, California, U.S.A. 